\title{
Implementasi Kurikulum 2013 Bagi Guru SMA Negeri Aceh Tamiang
}

\author{
Nursamsu* dan Baihaqi \\ Universitas Samudra Langsa, *Email: nursamsu05@gmail.com
}

\begin{abstract}
In order to meet the educational goals, teachers have to prepare the tools of learning. Those tools have the roles as the instrument of teaching and learning activities Teaching and learning activities have to be supported by interesting stages activities, so students have more focus and have the active roles in learning. The objectives of learning can be achieved if teachers can adapt the learning activities into the changing policies, one of them are, the 2013 curricula. This research aims to see the implementation of 2013 curicula in the learning activities of biology teachers in government highschool of Aceh Tamiang. The method used in this research is the descriptive qualitative. The samples are 10 biology teachers. The location of research are in government highschool in Aceh Tamiang, including SMA Negeri 1 Manyak Payed, SMA Negeri 2 Percontohan, SMA Negeri 1 Kejuruan Muda, SMA Negeri 2 patra Nusa dan SMA Negeri 2 Kejuruan Muda. The instruments of the research are 1) Observation 2) Interview. Result of this research shows that schools are implementing the 2013 curricula.However, the research shows that the implementation of 2013 curricula is not fully completed. This shows that socialization and the training are not fully implemented, the ineffective of the training of 2013 Curricula. Teachers are not in maximum effort in implementing the 2013 curricula because the limited of the organizing system, the resources are not sufficient, and the assessment that seems so difficult. The result of analysis above shows the teachers preparedness in implementing of 2013 curricula is categorized as not sufficient.
\end{abstract}

Keyword: Qualitative research, high school teacher, implementation of curriculum 2013

\section{PENDAHULUAN}

Seorang guru harus melakukan suatu perubahan dalam proses kegiatan belajar mengajar untuk meningkatkan prestasi belajar siswa dengan mendapatkan nilai memuaskan. Dengan cara melaksanakan proses kegiatan belajar mengajar dengan mengikuti dan mempelajari perubahan kurikulum yang telah ditetapkan oleh pemerintah. Hal ini kita dapat lihat pada kurikulum 2013 dimana guru dapat melaksanakan perubahan kurikulum sebagai suatu yang dinamis untuk menciptakan generasi yang mampu bersaing di masa depan.

Dengan adanya implementasi kurikulum 2013 pada guru biologi dalam pelaksanaan kegiatan pembelajaran ini dapat mempengaruhi prestasi belajar siswa. hal dapat kita lihat dari hasil penelitian bahwa guru sebagai pelaksana kurikulum 2013 telah menyusun rencana pelaksanaan pembelajaran (RPP) dengan cukup baik dengan rerata persentase 47.06\% (Yulianti, 2014:5).
Menurut Suwondo, dkk (2014:46), dalam penelitian juga mengatakan Persepsi guru biologi terhadap standar evaluasi kurikulum 2013 tergolong dalam kategori sangat baik untuk Sekolah Menengah Pertama dengan rerata 3,31 dan 3,20 untuk Sekolah Menengah Atas. Dengan demikian orientasi pembelajaran mengarah kepada proses pembelajaran siswa yang aktif atau pembelajaran berorientasi aktivitas siswa.

Kementeriaan Pendidikan Nasional menggulirkan kurikulum pada tahun 2013 yang memuat 4 kompetensi inti (KI) dan kompetensi dasar (KD). Sedangkan bagian yang menjadi kewenangan guru adalah materi pokok, indikator pencapaian kompetensi serta pengembangan strategi pembelajaran. yang mencakup pembelajaran tatap muka dan pengalaman belajar serta instrumen penilaiannya. Kalimat terakhir inilah yang merupakan tantangan sekolah dan para guru bagaimana menjabarkannya kedalam bentuk kegiatan pembelajaran di kelas, dimana guru biologi dapat melaksanakan pembelajaran biologi disertai dengan 
praktikum di laboratorium. Hal ini merupakan kendala yang dihadapi guru guru SMA Negeri yang ada di Kabupaten Aceh Tamiang

Berdasarkan permasalahan tersebut maka dari itulah saya melakukan penelitian untuk menciptakan guru yang professional dan melahirkan siswa generasi masa depan berkarakter,

yang memahami jati diri bangsanya dan menciptakan anak yang unggul, mampu bersaing ditingkat nasional Kesiapan guru sangat luas pengertiannya serta syarat yang harus dipenuhi untuk mengatakan bahwa guru siap dalam pelaksanaan untuk suatu program. Kesiapan guru merupakan kondisi seorang guru yang membuatnya siap untuk memberikan respon atau jawaban dengan menggunakan suatu cara dalam melaksanakan jabatan profesionalnya. Kurikulum 2013 sangat menuntut kesiapan guru dan sekolah dalam menghadapi kurikulum tersebut. Dalam hal ini sebaik apapun sebuah kurikulum, jika tidak didukung oleh kesiapan guru dan sekolah maka semua itu akan sia-sia.

Guru mempunyai peran yang besar dalam proses pembelajaran pada setiap pergantian kurikulum. Setiyanto (2013) menyatakan:Setidaknya ada empat aspek kompetensi guru yang perlu dipersiapkan dalam menghadapi kurikulum 2013, yaitu:

(1) Pertama, kompetensi guru dalam pemahaman substansi bahan ajar, kompetensi pedagogik. Didalamnya terkait dengan metodologi pembelajaran, yang nilainya dalam pelaksanaan uji kompetensi guru (UKG) baru mencapai 44,46. (2) Kedua, kompetensi akademik (keilmuan), ini juga penting, karena guru sesungguhnya memiliki tugas untuk bisa mencerdaskan peserta didik dengan ilmu an pengetahuan yang dimilikinya. Jika tidak, maka peserta didik tidak akan mendapatkan ilmu pengetahuan apa-apa. (3) Ketiga, kompetensi sosial. Guru sebaiknya memiliki kompetensi sosial, karena ia tidak hanya dituntut cerdas dan menyampaikan materi keilmuanya dengan baik, tetapi dituntut untuk secara sosial memiliki kompetensi yang memadai, baik terhadap teman sejawat, peserta didik maupun lingkunganya. (4) Keempat, kompe-tensi manajerial atau kepemimpinan. Pada diri gurulah sesungguhnya terdapat teladan, yang diharapkan dapat dicontoh oleh peserta didiknya. Seperti pada slogan ing ngarso sung tulodho, ing madya mangun karso dan tut wuri handayani.

Melalui empat tujuan itu diharapkan siswa memiliki kompetensi sikap, keterampilan, dan pengetahuan yang jauh lebih baik. Sehingga akan menghasilkan siswa yang lebih kreatif, inovatif, dan lebih produktif. Hal ini yang harus terus ditingkatkan sehingga guru berperan besar di dalam mengimplementasikan tiap proses pembelajaran pada kurikulum 2013 untuk mencapai tujuan pembelajaran yang diinginkan. Implementasi dalam Kamus Besar Bahasa Indonesia diartikan sebagai pelaksanaan atau penerapan. Artinya yang dilaksanakan dan diterapkan adalah kurikulum yang telah dirancang/didesain untuk kemudian dijalankan sepenuhnya. Implementasi kurikulum merupakan suatu kegiatan yang bertujuan untuk mewujudkan atau melaksanakan kurikulum (dalam arti rencana tertulis) ke dalam bentuk nyata di kelas, yaitu terjadinya proses transmisi dan transformasi segenap pengalaman belajar kepada peserta didik. Fullan dalam (Miller dan Seller, 1985:246) mengartikan implementasi kurikulum sebagai "the putting into practice of an idea, program or set of activities which is new to the individual or organization using it". Lebih lanjut dijelaskan bahwa implementasi kurikulum merupakan suatu proses penerapan konsep, ide, program, atau tatanan kurikulum ke dalam praktik pembelajaran atau aktivitas-aktivitas baru sehingga terjadi perubahan pada sekelompok orang yang diharapkan untuk berubah.

Selanjutnya Mulyasa (2009:179) menegaskan bahwa implementasi kurikulum setidaknya dipengaruhi oleh tiga faktor yaitu : (1) Karakteristik kurikulum yang mencakup ruang lingkup ide baru suatu kurikulum dan kejelasannya bagi pengguna di lapangan, (2) Strategi implementasi yaitu strategi yang digunakan dalam implementasi, seperti diskusi profesi, 
seminar, penataran, loka karya, penyedian buku kurikulum, dan kegiatan-kegiatan yang dapat mendorong penggunaan kurikulum dilapangan, (3) Karakteristik pengguna kurikulum, yang meliputi pengetahuan, keterampilan, nilai, dan sikap guru terhadap kurikulum, serta kemampuannya untuk merealisasikan kurikulum dalam pembelajaran.

Kurikulum 2013 bertujuan untuk mempersiapkan manusia Indonesia agar memiiliki kemampuan hidup sebagai pribadi dan warga Negara yang beriman, produktif, kreatif, inovatif dan afektif serta mampu berkontribusi pada kehidupan bermasyarakat,berbangsa, bernegara, dan peradaban dunia. Pengembangan Kurikulum 2013 menekankan pengembangan kompetensi pengetahuan, keterampilan, dan sikap secara holistik. Hal ini sejalan pula dengan pengembangan kurikulum berbasis kompetensi yang telah dirintis pada tahun 2004 dengan mencakup kompetensi sikap, pengetahuan dan keterampilan secara terpadu. Berdasarkan uraian di atas, dapat disimpulkan bahwa Implementasi Kurikulum 2013 merupakan penyempurnaan kurikulum yang berbasis karakter berdasarkan pengembangan dari kurikulum sebelumnya yaitu KTSP 2006, pembelajaran diharapkan dapat membentuk karakter dan kompetensi siswa.Untuk menjamin keterlaksanaan Implementasi Kurikulum 2013 dalam pelaksanaan pembelajaran, juga harus diperkuat peran pendampingan dan pemantauan oleh pusat dan daerah.

\section{METODE}

Dalam penelitian ini menggunakan metode deskriptif yang bersifat kualitatif, karena data yang dikumpulkan berupa informasi kata - kata, tulisan, serta perilaku yang diamati walaupun hanya menyangkut perilaku pendukung yang hanya dapat diamati secara pasif oleh orang luar organisasi. Sampel penelitian adalah lima sekolah, yaitu SMA Negeri 2 Patra Nusa, SMA Negeri 1 Manyak Payed, SMA Negeri 2 Percontohan, SMA Negeri 1 Kejuruan Muda dan SMA Negeri 2 Kejuruan Muda di Kabupaten Aceh
Tamiang. Dalam penelitian ini, 5 (tiga) Sekolah SMA Negeri Aceh Tamiang yang dipilih dengan pertimbangan tertentu. Pertimbangan tertentu ini adalah dikarenakan sekolah yang dipilih sudah menerapkan dan melanjutkan kurikulum 2013, keterbukaan kepala sekolah dan dewan guru untuk menerima perubahan dalam proses pembelajaran, sekolah tersebut merupakan sekolah yang pernah peneliti menjadi tenaga pengajar sehingga akan memudahkan peneliti menjelajahi situasi guru dalam kesiapan guru mengimplementasikan kurikulum 2013. Adapun teknik pengumpulan data yang dilakukan dalam penelitian ini diperoleh dengan menggunakan instrumen penelitian berupa wawancara dan observasi.

\section{HASIL DAN PEMBAHASAN}

\section{Hasil Dari Observasi Kesekolah SMA Negeri Aceh Tamiang}

\section{Sekolah SMA Negeri 1 Kejuruan Muda Kabupaten Aceh Tamiang}

Observasi Survey Lapangan pada tanggal 26 - April - 2016 yang dilaksanakan oleh Tim Penelitian di Sekolah SMA Negeri 1 Kejuruan Muda Aceh Tamiang dengan wakil kepada sekolah bagian kurikulum bernama Dra. Lindawati Waris. Adapun tujuan observasi kami adalah untuk melakukan penelitian dimana guru biologi dan siswa untuk diberikan pengetahuan kurikulum 2013 hal tersebut disambut dengan baik dan langsung menentukan jadwal kapan kami pelaksanakan penelitian pada tanggal 29 April - 2016 sampai 30 - April - 2016. Dimana kami komunikasi sama wakil kepada sekolah kami ambil sampel guru 2 orang.

\section{Sekolah SMA Negeri 1 Manyak Payed Kabupaten Aceh Tamiang}

Observasi Survey Lapangan pada tanggal 26 - April - 2016 yang dilaksanakan oleh Tim Penelitian di Sekolah SMA Negeri 1 Manyak Payed Aceh Tamiang dengan wakil kepada sekolah bagian kurikulum bernama Nila 
Diana, S.Pd. Adapun tujuan observasi kami adalah untuk melakukan penelitian dimana guru biologi dan siswa untuk diberikan pengetahuan kurikulum 2013, hal tersebut disambut dengan baik dan langsung menentukan jadwal kapan kami pelaksanakan penelitian pada tanggal $03-$ Mei - 2016 sampai 04 - Mei - 2016. Dimana kami komunikasi sama wakil kepada sekolah kami ambil sampel guru 2 orang.

\section{Sekolah SMA Negeri 2 Percontohan Kabupaten Aceh Tamiang}

Observasi Survey Lapangan pada tanggal 26 - April - 2016 yang dilaksanakan oleh Tim Penelitian di Sekolah SMA Negeri 2 Percontohan Aceh Tamiang dengan wakil kepada sekolah bagian kurikulum bernama Ernawati, S.Pd. Adapun tujuan observasi kami adalah untuk melakukan penelitian dimana guru biologi dan siswa untuk diberikan pengetahuan kurikulum 2013, hal tersebut disambut dengan baik dan langsung menentukan jadwal kapan kami pelaksanakan penelitian pada tanggal 09 - Mei - 2016 sampai 10 Mei - 2016. Dimana kami komunikasi sama wakil kepada sekolah kami ambil sampel guru 2 orang.

\section{Sekolah SMA Negeri 2 Kejuruann Muda Kabupaten Aceh Tamiang}

Observasi survey lapangan pada tanggal 26 - April - 2016 yang dilaksanakan oleh Tim Penelitian di Sekolah SMA Negeri 1 Manyak Payed Aceh Tamiang dengan wakil kepada sekolah bagian kurikulum bernama Nurasiah, S.Pd. Adapun tujuan observasi kami adalah untuk melakukan penelitian dimana guru biologi dan siswa untuk diberikan pengetahuan kurikulum 2013, hal tersebut disambut dengan baik dan langsung menentukan jadwal kapan kami pelaksanakan penelitian pada tanggal 11 - Mei - 2016 sampai 12 - Mei - 2016. Dimana kami komunikasi sama wakil kepada sekolah kami ambil sampel guru 2 orang.

\section{Sekolah SMA Negeri 2 Patra Nusa Kabupaten Aceh Tamiang}

Observasi survey lapangan pada tanggal 26 - April - 2016 yang dilaksanakan oleh Tim Penelitian di Sekolah SMA Negeri 1 Patra Nusa Aceh Tamiang dengan wakil kepada sekolah bagian kurikulum bernama Ernawati, S.Pd Adapun tujuan observasi kami adalah untuk melakukan penelitian dimana guru biologi dan siswa untuk diberikan pengetahuan kurikulum 2013 dan pelatihan praktikum, hal tersebut disambut dengan baik dan langsung menentukan jadwal kapan kami pelaksanakan penelitian pada tanggal 16 Mei - 2016 sampai 17 - Mei - 2016. Dimana kami komunikasi sama wakil kepada sekolah kami ambil sampel guru 2 orang.

\section{Hasil Wawancara Guru}

\section{SMA Negeri 1 Kejuruan Muda Kabupaten Aceh Tamiang Dalam Pelaksanaan Kurikulum 2013}

Pada saat ditanyak tentang bagaimana pelaksanaan kurikulum 2013 kepada Ibu Dra. Cut Lailatul Kadri bahwa pelaksanaan kurikulum 2013 sudah sangat bagus, dimana guru hanya sebagai fasilitator dalam proses pembelajaran dan lebih menekankan ke anak didiknya untuk aktif dan kreatif dalam pembelajaran hingga menemukan permasalahan dan materi yang disampaikan, akan tetapi kami belum menerapkan kurikulum 2013 terhadap proses belajar dan pembelajaran.

Selanjutnya Drs. Muhammad Yahya mengungkapkan bahwa sekolah kami belum menerapkan kurikulum 2013, menurut pendapat saya bahwa pelaksanaan kurikulum 2013 semestinya dilaksanakan di kelas yang sudah unggul atau sekolah yang unggul dimana anak didiknya sudah sangat siap ketika dilaksanakan kurikulum 2013. Akan tetapi juga dibutuhkan guru yang pandai membuat kelas yang nyaman dan aktif dalam pelaksanaan kurikulum 2013. Oleh karena itu guru harus benar-benar siap dalam pelaksanaan kurikulum 2013 sehingga tujuan pembelajaran yang diharapkan oleh kurikulum 2013 berjalan dengan lancar dan mencapai tujuan yang maksimal. 
Sejalan dari pendapat kedua guru biologi di atas dapat disimpulkan bahwa secara teori dan materi yang ada pada kurikulum 2013 ini guru sudah cukup memahami isi buku siswa dan buku guru dan mengetahui bagaimana seharusnya pelaksanaan pembelajaran di kurikulum 2013, namun dalam penerapan guru masih kurang dalam menerapkan atau melaksanakan sebagaimana mestinya.

\section{SMA Negeri 1 Manyak Payed Kabupaten Aceh Tamiang Dalam Pelaksanaan Kurikulum 2013}

Menurut pendapat Bapak Zulbahri, S.Pd bahwa pelaksanaan kurikulum 2013 belum berjalan dengan efektif, sehingga disekolah SMA Negeri yang ada di tamiang belum menerapkan kurikulum 2013 khususnya disekolah kami, dikarenakan belum sepenuhnya penguasaan kurikulum 2013. Sejalan dengan pendapat di atas Ibu Yusnidar, S.Pd juga menjelaskan bahwa pelaksanaan kurikulum masih sangat minim dilaksanakan oleh seorang guru, apalagi guru yang belum sama sekali mendapatkan pelatihan yang matang dalam pelaksanaannya, alangkah lebih baiknya pelaksanaan kurikulum 2013 ini lebih ditingkatkan dan diberikan pengetahuan kepada seluruh guru untuk tata cara bagaimana mengajarkan dengan menggunakan banyak model dan metode dalam proses pembelajaran yang ada pada kurikulum 2013.

Dari pernyataan di atas dapat disimpulkan bahwa kegiatan pelaksanaan kurikulum 2013 belum terlaksanakan, dikarena guru - guru belum matang tentang ilmu tata cara bagaimana mengajarkan dengan menggunakan banyak model, metode dan praktek dalam proses pembelajaran yang ada pada kurikulum 2013.

\section{SMA Negeri 2 Percontohan Kabupaten Aceh Tamiang Dalam Pelaksanaan Kurikulum 2013}

Menurut pendapat Ibu Rasiah, S.Pd., M.Pd bahwa kurikulum 2013 belum dilaksanakan disekolah kami, karena belum siap dari informasi ilmu untuk dilaksanakan dalam proses kegiatan belajar dan pembelajaran. Dalam menerapan kurikulum 2013 harus mempunyai guru ungul dibidang kompetensi sehingga mencipkan anak yang berprestasi. Sedangkan menurut pendapat Ibu Elly Sahrani, S.Pd bahwa pelaksanaan kurikulum 2013 ini sangat susah dilaksanakan, dikarekan pelaksanaannya guru harus benar paham tentang teori dan praktek sedangakan banyak guru yang hanya teori tetapi tidak ada ilmu praktek.

Kesimpulan dari kedua guru diatas tentang kurikulum 2013 mengatakan bahwa kurikulum 2013 belum dilaksanakan disekolah kami. Banyak guru - guru belum siap tentang ilmu dalam pelaksanaan kurikulum 2013.

\section{SMA Negeri 2 Percontohan Kabupaten Aceh Tamiang Dalam Pelaksanaan Kurikulum 2013}

Menurut pendapat Ibu Rasiah, S.Pd., M.Pd bahwa kurikulum 2013 belum dilaksanakan disekolah kami, karena belum siap dari informasi ilmu untuk dilaksanakan dalam proses kegiatan belajar dan pembelajaran. Dalam menerapan kurikulum 2013 harus mempunyai guru ungul dibidang kompetensi sehingga mencipkan anak yang berprestasi. Sedangkan menurut pendapat Ibu Elly Sahrani, S.Pd bahwa pelaksanaan kurikulum 2013 ini sangat susah dilaksanakan, dikarekan pelaksanaannya guru harus benar paham tentang teori dan praktek sedangakan banyak guru yang hanya teori tetapi tidak ada ilmu praktek.

Kesimpulan dari kedua guru diatas tentang kurikulum 2013 mengatakan bahwa kurikulum 2013 belum dilaksanakan disekolah kami. Banyak guru - guru belum siap tentang ilmu dalam pelaksanaan kurikulum 2013.

\section{SMA Negeri 2 Kejuruan Muda \\ Kabupaten Aceh Tamiang Dalam Pelaksanaan Kurikulum 2013}

Menurut pendapat Ibu Hasana Lifa, S.Pd tentang kurikulum 2013 belum dilaksanakan disekolah kami. Guru - guru disekolah kami belum siap untuk 
melaksanakan kurikulum tersebut. menurut saya pelaksanaan kurikulum 2013 ini sudah sangat bagus, tetapi harusnya tidak terlalu banyak pembelajaran dalam satu subtema dan hal itu membuat saya bingung dan juga pada proses pembelajarannya materi yang ingin disampaikan tidak mendetail hanya menjelaskan secara dasar. contohnya pada pembelajaran biologi maunya disetiap materi ada teori dan prakteknya. Hal itu juga membuat kami mudah untuk menjelaskan kepada anak - anak dalam teori maupun prakteknya.

Selanjutnya Ibu Nurfitriani Zen, S.Pd mengatakan bahwa pelaksanaan kurikulum 2013 di mestinya menggunakan materi yang per mata pelajaran seperti KTSP yang sebelumnya, dimana penekanan materi yang luas dan lebih banyak pengetahuan yang didapatkan oleh anak didik.

Dapat diambil kesimpulan dari pernyataan guru biologi SMA Negeri 2 Kejuruan Muda bahwa pelaksanaan kurikulum 2013 masih kurang efektif alasannya dikarenakan materi yang disampaikan masih dasar dan tidak mendetail materi yang ingin disampaikan.

\section{SMA Negeri 2 Patra Nusa Kabupaten Aceh Tamiang Dalam Pelaksanaan Kurikulum 2013}

Berdasarkan wawancara dengan Ibu Ayjumirta, S.Pd tentang pelaksanaan proses pembelajaran dalam kurikulum 2013 mengatakan bahwa pelaksanaan proses pembelajaran pada kurikulum 2013 belum dilaksanakan, disebabkan belum siap guru guru kurikulum 2013. Dalam pelaksanaan kurikulum 2013 ini lebih menekankan kepada sikap, pengetahun dan keterampilan siswa. Dalam hal ini juga sisawa dituntut harus aktif dan kreatif dalam proses pembelajaran, guru hanya memberikan arahan dan masukan untuk memudahkan siswa menalar tentang materi yang diajarkan.

Selanjutnya Ibu Ernawati, S.Pd mengemukakan bahwa pelaksanaan proses pembelajaran kurikulum 2013 harus menggunakan pendekatan saintifik dimana anak disuruh mengamati, menalar, menanya, mengkomunikasikan dan mengumpulkan informasi. Sehingga dalam proses pelaksanaan pembelajaran juga siswa diberikan penilaian baik itu penilaian individu maupun penilaian kelompok. Hal ini menyebabkan sekolah kami tidak melaksanakannya.

Dari pendapat guru-guru di atas dapat dipahami bahwa dalam proses pelaksanaan pembelajaran tidak lepas dari bagaimana guru mendesain pembelajaran sehingga terlihat keaktifan anak dalam proses pembelajaran. Dalam proses pelaksanaan pembelajaran guru harus melakukan penanaman religius, penanaman nilai sosial yang dapat dikaitkan terciptanya tiga ranah sikap, pengetahuan dan keterampilan. Sebab itulah mereka tidak belum siap untuk melaksanakan kurikulum 2013 disekolah mereka.

\section{SIMPULAN}

Dari hasil penelitian dalam pelaksanaan kurikulum 2013 di setiap sekolah yang menjadi sampel dalam penelitian kami. Diketahui dari masing - masing guru yang diwawancara bahwa sekolah melaksanakan kurikulum 2013. Hal ini ditunjukkan pada belum meratanya sosialisasi dan pelatihan untuk guru-guru yang diadakan oleh pemerintah, belum efektifnya pelaksanaan pelatihan kurikulum 2013 yang diadakan oleh pemerintah untuk guru-guru, belum maksimalnya guru-guru dalam pelaksanaan pembelajaran pada kurikulum 2013 yaitu pengelolaan yang masih sangat terbatas, sarana dan prasarana yang belum lengkap, serta penilaian yang dianggap masih sangat sulit.

\section{DAFTAR PUSTAKA}

Miller, John P and Seller, Wayne. 1985. Curriculum Perspective and Practice. United States: Longman, Inc.

Mulyasa, E. 2009. Standar Kompetensi dan Sertifikasi Guru. Bandung:Remaja Rosdakarya.

Setiyanto, Agus. 2013. Paper Kesiapan Guru Menyambut Pelaksanaan Kurikulum2013.http://ndarima.blogspot.com /2013/11/behaviorrldefaultvmlo.html.Diakse s6 November 2013.

Suwondo, Mariani Natalina L. dan Vivi Triska. 2014. Persepsi Guru Biologi Menghadapi 
Jurnal Pendidikan Biologi, Vol. 5, No. 3, Edisi Agustus 2016

Kurikulun 2013 Pada Tingkat. Universitas Riau Pekanbaru: Jumal Biogenesis, Vol 10, Nomor 2, Februari 2014.

Yutianti. 2014. Tingkat Keterlaksanaan Implementasi Kurikulum 2013 Dalam
Pembelajaran Biologi SMA Negeri di Kabupaten Dompu Tahun Ajaran 2013/2014. Matakaram. Artikel program Studi Pendidikan Biologi Universitas Mataram. 